\title{
Stability and Microstructure of Emulsion System in Sterilized Kai-yor (Thai Chicken Sausage)
}

\author{
Nut Thephuttee ${ }^{1,2^{*}}$ and Prapasri Theprugsa ${ }^{1,2}$ \\ ${ }^{1}$ Department of Food Science and Technology, Faculty of Science and \\ Technology, Thammasat University, Pathum Thani 12120, Thailand \\ ${ }^{2}$ Thammasat University Center of Excellence in Food Science and Innovation, \\ Thammasat University, Pathum Thani 12120, Thailand \\ *Corresponding author. E-mail: nutthephuttee@gmail.com \\ https//:doi.org/10.12982/CMUJNS.2020.0050 \\ Received: October 10, 2019 \\ Revised: December18, 2019 \\ Accepted: December 22, 2019
}

\begin{abstract}
Stability and microstructure of meat emulsion in Kai-yor (Thai chicken sausage) formulated with 4 different lipids and subjected to 2 levels of heat treatment were evaluated. Types of lipids included chicken fat (control), frozen rice bran oil (RBO), pre-emulsified $\mathrm{RBO}$ with soy protein isolate (SPI), and pre-emulsified $R B O$ with a mixture of sodium caseinate and microbial transglutaminase (SC+MTG). The heat treatments were cooking and cooking followed by sterilization (cook-sterilization). Meat emulsions were prepared, steamed cooked, packaged in a retort pouch and sterilized. The results showed that frozen and pre-emulsified $\mathrm{RBO}$ with $\mathrm{SC}+\mathrm{MTG}$ increased the stability of meat emulsion indicated by a reduction in fluid release. Hardness and chewiness of all reformulated Thai chicken sausages were higher than those of the control heated by cooking and cook-sterilization. The sterilization process negatively affected texture of all samples, nevertheless the meat emulsion formulated with pre-emulsified RBO with SC+MTG exhibited the lowest percentage decrease in hardness and chewiness. Scanning electron micrographs indicated that differences in the lipid phase affected the microstructure of meat emulsions. Sterilization altered and disrupted the protein matrix to different extents depending on the type of lipid. Replacing chicken fat with pre-emulsified $R B O$ with $S C+M T G$ resulted in greater formation of a protein matrix which was less severely damaged after sterilization than other lipids. It can be concluded that substitution of chicken fat by both frozen and pre-emulsified RBO (with SPI or SC+MTG) showed the potential for producing a cooked meat emulsion with better quality.
\end{abstract}




\section{However to achieve a satisfactory quality of sterilized meat emulsion, pre-emulsified RBO with SC+MTG offered superior alternative.}

Keywords: Microstructure, Sterilization, Meat emulsion, Rice bran oil, Pre-emulsified oil

\section{INTRODUCTION}

Kai-yor or Thai chicken sausage is an emulsion-type meat product and contains a fairly large amount of lipid commonly as high as $30 \%$. Consumption of this product could pose an adverse health effect for the consumer. It has been indicated that consumption of high lipid content diets especially those that contain high saturated fatty acids and cholesterol is related to various health problems such as obesity, high blood pressure, and heart disease. World Health Organization has recommended that $15-30 \%$ of energy in our daily diet should come from lipids and not over than $10 \%$ of those should come from saturated fats. Thus, the consumer demand for reduced fat meat products has been continuously escalating. (Jimenez-Colmenero et al., 2001; Vural and Javidipour, 2002; Oezvural and Vural, 2008; Jimenez-Colmenero et al., 2010a)

Replacement of animal fat in meat products by different types of vegetable oil is one of the methods to help reduce saturated fat and cholesterol contents in the product and this method has less effect on meat emulsion stability than replacing animal fat with other types of fat replacers (Choi et al., 2010; Jimenez-Colmenero et al., 2010a; Shao et al., 2011; Youssef and Barbut, 2011). Previous studies have shown different patterns in utilization of vegetable oil to replace animal fat in emulsion-type meat products including chilled oil (Youssef and Barbut, 2011), frozen oil (Saksomboon and Theprugsa, 2015), pre-emulsified oil (vegetable oil-in-water emulsion) using various non-meat proteins as an emulsifier such as soy protein or casein and possibly with the use of microbial transglutaminase enzyme (Herrero et al., 2012). Rice bran oil is one of the suitable choices of vegetable oil that can be substituted for animal fat in meat products. This oil is comprised of large quantities of mono- and polyunsaturated fatty acids and also contains phytosterol and oryzanol that exhibit health promoting functions such as anti-free radical and reduction of low density lipoproteins (LDL). Rice bran oil is domestically produced from abundant rice bran, a by-product from rice milling industries which are the major agro-business in Thailand and consumer demand for this oil has risen in the healthy food segment. Previous research has indicated that rice bran oil can be used as a chicken fat replacer in Thai chicken sausage (Saksomboon and Theprugsa, 2015).

Currently, the consumers are more interested in ready-to-eat food with extended shelf-life and produced by a sterilization process, especially those that are packed in a retort pouch. However, most of the meat product including Thai 
chicken sausage still produced by a cooking method equivalent to pasteurization only has a shelf-life of 15-30 days at refrigeration temperatures. This lead to the research that successfully developed a formulation and processing method for sterilized Thai chicken sausage packed in transparent retort pouch (Phisantia and Theprugsa, 2018).

Previous research in the field of microstructure of meat emulsion systems reformulated with various forms of vegetable oil are limited to products that are heat treated at pasteurization levels (Jimenez-Colmenero et al., 2010b; DelgadoPando et al., 2011; Herrero et al., 2012; Marchetti et al., 2013; Genccelep et al., 2015). Thus, this research aimed to study some physico-chemical properties, textural properties and morphological characteristics of meat emulsion systems incorporated with different types of rice bran oil followed by sterilization process.

\section{MATERIALS AND METHODS}

\section{Materials}

Fresh chicken meat (single breast fillet-skin on) was obtained from a local grocery store (Ek-Chai Distribution System Co. Ltd., Bangkok, Thailand). The meat was deskinned and apparent fat and connective tissues were removed. The trimmed meat was diced and ground twice in a meat grinder with $2 \mathrm{~mm}$ plate (Tre Spade TC-12 INOX, FACEM S.p.A., Turin, Italy). Ground meat was pre-blended by mixing with $1.05 \%$ sodium chloride (Chemipan Corporation, Bangkok, Thailand) for $1 \mathrm{~min}$ in a kneading-mixing machine (Mainca RM-20, Equipamientos Carnicos S. L., Barcelona, Spain), then packed in polyethylene (PE) bags, frozen and stored at $-18^{\circ} \mathrm{C}$ for $12 \mathrm{~h}$.

Chicken fat was bought from a nearby slaughterhouse (Central Poultry Processing Co. Ltd., Pathum Thani, Thailand). The fat was trimmed of connective tissue, sliced into thin shreds, then packed in PE bags, frozen and stored at $-18^{\circ} \mathrm{C}$ for $12 \mathrm{~h}$. Frozen rice bran oil was prepared by packing rice bran oil (RBO) containing 4,000 ppm of oryzanol (King Rice Oil Group, Thai Edible Oil Co. Ltd.) in PE bags, freezing and storing at $-18^{\circ} \mathrm{C}$ for $12 \mathrm{~h}$.

The ingredients used for preparation of pre-emulsified RBO included RBO (same as mentioned above); soy protein isolate (SPI) composed of $90 \%$ protein (PRO 500A, Vicchi Enterprise Co. Ltd., Bangkok, Thailand); sodium caseinate (SC) composed of $80 \%$ protein (ECCO 2,300, Erie Food International Inc., Illinois, USA), and microbial transglutaminase (MTG) composed of $1 \%$ transglutaminase and 99\% maltodextrin with a standard enzyme activity of approximately 100 units/g (ACTIVA WM, Ajinomoto Foods Europe S.A.S., Paris, France). RBO was stored at $4^{\circ} \mathrm{C}$ for $12 \mathrm{~h}$ prior to use.

The food additive and seasonings used for manufacturing of the sausage were sodium triphosphate (STP) (Chemipan Corporation, Bangkok, Thailand), monosodium glutamate (MSG) (Ajinomoto Thailand Co. Ltd., Bangkok, 
Thailand), sugar (Mitr Phol Sugar Corporation, Bangkok, Thailand), ground white pepper (Artchit International Pepper and Spice Co. Ltd., Bangkok, Thailand), fish sauce (Pichai Fish Sauce Co. Ltd., Bangkok, Thailand), fresh garlic and shallot (Ek-Chai Distribution System Co. Ltd., Bangkok, Thailand). Garlic and shallots were hand peeled and ground then packed in PE bags and stored at $4^{\circ} \mathrm{C}$ for $12 \mathrm{~h}$.

\section{Preparation of pre-emulsified rice bran oil}

Two types of pre-emulsified RBO were formulated according to JimenezColmenero et al. (2010b): (1) pre-emulsified RBO with SPI (RBO/SPI) and (2) pre-emulsified RBO with a mixture of SC and MTG (RBO/SCM). Preparation methods for RBO/SPI and RBO/SCM were modified based on that described by Herrero et al. (2012). The initial step was preparation of water phase by mixing 1 part $(5.26 \%)$ of SPI or SC with 8 parts $(42.11 \%)$ of cold water (temperature below $4^{\circ} \mathrm{C}$ ) for $2 \mathrm{~min}$ in a food processor (Panasonic MK-5087M, Panasonic Malaysia Sdn. Bhd., Selangor, Malaysia). In the case of RBO/SCM, MTG (6.81\% of SC) was incorporated into the water phase by dry mixing with SC before mixing with cold water. Then 10 parts $(52.63 \%)$ of RBO were gradually added to the water phase during emulsification in a food processor for $3 \mathrm{~min}$. All percentages were expressed as $\mathrm{w} / \mathrm{w}$. The food processor was pre-chilled by placing its knife blade, bowl, and lid in a cold room $\left(4^{\circ} \mathrm{C}\right)$ for $1 \mathrm{~h}$. The temperature of pre-emulsified $\mathrm{RBO}$ was less than $10^{\circ} \mathrm{C}$ at the end of process. $\mathrm{RBO} / \mathrm{SPI}$ and $\mathrm{RBO} / \mathrm{SCM}$ were then packed in PE bags and stored at $4{ }^{\circ} \mathrm{C}$ until use (no later than $4 \mathrm{~h}$ ).

\section{Preparation of Thai chicken sausage}

Four different Thai chicken sausages were formulated as shown in Table 1. Control formulation with chicken fat (Y/CF) was as reported by Saksomboon and Theprugsa, 2015. Other formulations included the sausages incorporated with frozen RBO (Y/RBO), pre-emulsified RBO with SPI (Y/SPI) and pre-emulsified RBO with a mixture of SC and MTG (Y/SCM).

Table 1. Formulation $(\% \mathrm{w} / \mathrm{w})$ of Thai chicken sausages with different types of lipid.

\begin{tabular}{|c|c|c|c|c|c|c|}
\hline \multirow{2}{*}{ Samples } & \multirow{2}{*}{$\begin{array}{l}\text { Pre-blended } \\
\text { meat }\end{array}$} & \multirow{2}{*}{$\begin{array}{l}\text { Chicken } \\
\text { fat }\end{array}$} & \multirow{2}{*}{$\begin{array}{l}\text { Frozen } \\
\text { RBO }\end{array}$} & \multicolumn{2}{|c|}{ Pre-emulsified RBO } & \multirow{2}{*}{ Ice } \\
\hline & & & & RBO/SPI & RBO/SCM & \\
\hline $\mathrm{Y} / \mathrm{CF}$ & 67.98 & 20.43 & - & - & - & 6.81 \\
\hline $\mathrm{Y} / \mathrm{RBO}$ & 67.98 & - & 20.43 & - & - & 6.81 \\
\hline Y/SPI & 67.98 & - & - & 20.43 & - & 6.81 \\
\hline Y/SCM & 67.98 & - & - & - & 20.43 & 6.81 \\
\hline
\end{tabular}

Note: All formulated with $0.20 \%$ STP, $0.30 \%$ MSG, $1.20 \%$ sugar, $0.65 \%$ fish sauce, $0.32 \%$ ground white pepper, $0.43 \%$ garlic, and $0.63 \%$ shallot. 
Thai chicken sausage was prepared according to the method described by Phisantia and Theprugsa, 2018. Pre-blended chicken meat and chicken fat packages were thawed prior to use (the final temperature was $0-1{ }^{\circ} \mathrm{C}$ ). The preblended meat, STP and two-thirds of ice were chopped for $2 \mathrm{~min}$ in a food processor (Panasonic MK-5087M, Panasonic Malaysia Sdn. Bhd., Selangor, Malaysia). Chicken fat, frozen RBO or pre-emulsified RBOs was added (depending on the formulation) to chopped meat and chopped again for $1 \mathrm{~min}$. The seasonings and rest of the ice were added and mixed for 2 min until the homogeneous meat emulsion (or batter) was formed. The meat emulsion temperature of all formulations was less than $12^{\circ} \mathrm{C}$ at the end of process.

The meat batter (approximately $600 \mathrm{~g}$ ) was stuffed into a 9x12x6 cm Teflon coated aluminum pan with sliding lid and cooked by steaming in a batch steam cooker at $100^{\circ} \mathrm{C}$ for $60 \mathrm{~min}$. The geometrical center of the product was at least $75^{\circ} \mathrm{C}$ by the end of cooking process. Once cooking was complete, the cooked meat batter was cooled by placing in an iced water bath for 15 min (the final temperature was approximately $25^{\circ} \mathrm{C}$ ). The cooked sausage was removed from the pan and divided into smaller $3 \times 5 \mathrm{~cm}$ pieces with $2 \mathrm{~cm}$ thickness weighing 26-31 g per piece. The cooked sausage samples were packed without vacuum in $\mathrm{PE}$ bags and stored at $4^{\circ} \mathrm{C}$ until further use.

\section{Sterilization process}

Four different sterilized Thai chicken sausage samples: YS/CF, YS/RBO, YS/SPI, and YS/SCM were processed from each cooked sausage sample: $\mathrm{Y} / \mathrm{CF}, \mathrm{Y} / \mathrm{RBO}, \mathrm{Y} / \mathrm{SPI}$, and Y/SCM, respectively. Sterilized sausage was prepared according to the method of Phisantia and Theprugsa (2018) with slight differences in heating conditions. The cooked sausages were packed in a $7 \times 12$ $\mathrm{cm}$ transparent retort pouch (without aluminum foil layer) (AlOx coated PET 13/OPA 15/CPP 70, Royal Meiwa Pax Co. Ltd., Samut Sakhon, Thailand) and vacuum sealed by a tabletop vacuum sealing machine (MULTIVAC C 200, MULTIVAC Sepp Haggenmüller SE \& Co. KG, Wolfertschwenden, Germany) which was set to 10 mbar pressure. Thirty pouches were placed on each tray (total of 10 trays) in a horizontal batch steam water spray retort (KM-P95SS, KM Grand Pack Co. Ltd., Bangkok, Thailand) and sterilized at $122^{\circ} \mathrm{C}$. The schedule process (time-temperature-pressure combination) for heat sterilization which including cooling period was devised beforehand to deliver the product adequate heat for achieving sterilization value $\left(\mathrm{F}_{0}\right)$ in the range of 12-15 min. The temperature of sterilized product at the end of cooling period was less than $35^{\circ} \mathrm{C}$. The sterilized sausage samples were stored at $4{ }^{\circ} \mathrm{C}$ until analysis.

\section{Emulsion stability}

Emulsion stability of different pre-emulsified RBOs and different meat emulsions were determined based on the method described by JimenezColmenero et al. (2010b). The stability was assessed by 3 parameters: total fluid release (TFR), water release (WR), and fluid residue (FR). Approximately $50 \mathrm{~g}$ 
of pre-emulsified RBO or meat emulsion sample were weighed and stuffed into a $50 \mathrm{~mL}$ round bottom centrifuge tube (Nalgene polysulfone Oak Ridge tube with polypropylene screw cap, Thermo Fisher Scientific Inc., Massachusetts, USA). The tube was centrifuged at $2,500 \mathrm{~g}$ for $15 \mathrm{~min}$ at $4{ }^{\circ} \mathrm{C}$ in a refrigerated centrifuge (Jouan CR3i, Thermo Fisher Scientific Inc., Massachusetts, USA), and heated in a water bath at $70^{\circ} \mathrm{C}$ for $30 \mathrm{~min}$. Then, the tube was opened, attached upside down to a laboratory retort stand by means of a ring clamp, and left for $50 \mathrm{~min}$ to release the separated fluid. The released fluid was collected in a reusable aluminum sample container (moisture content tin with lid) and weighed. TFR was calculated from the weight of collected fluid and expressed as $\%(\mathrm{w} / \mathrm{w})$ of initial sample weight. The fluid was heated for $16 \mathrm{~h}$ at $105^{\circ} \mathrm{C}$ in a hot air oven. WR was calculated from weight loss after heating and expressed as $\%(\mathrm{w} / \mathrm{w})$ of initial sample weight. FR was calculated as the difference between TFR and WR. The experiment was repeated 8 times for each sample. For interpretation purpose, the term fluid residue was used instead of fat release that was mentioned in Jimenez-Colmenero et al., 2010b since the method was not directly measured the amount of lipid in the released fluid and only determined the weight of residue left after water was evaporated. The released fluid also was not only comprised of water and lipid but contained other components such as protein or salt.

\section{Texture profile analysis}

Texture profile analysis (TPA) of different cooked and sterilized sausage samples was performed as described by Jimenez-Colmenero et al., 2010b and Phisantia and Theprugsa (2018). The assay was conducted at room temperature $\left(25-30^{\circ} \mathrm{C}\right)$ by using a texture analyzer (TA.XT.plus, Stable Micro Systems, Surrey, UK) with a $50 \mathrm{~mm}$ diameter aluminum flat-ended cylindrical probe $(\mathrm{P} / 50)$ attached to a $50 \mathrm{~kg}$ load cell. Sausage samples were cut at the center into a $15 \times 15 \times 15 \mathrm{~mm}$ cube and compressed at $40 \%$ strain and speed of $1 \mathrm{~mm} / \mathrm{s}$. Texture parameters were calculated as followed: hardness $(\mathrm{N})=$ peak force at first compression; cohesiveness $(\%)=$ ratio of work done under the second compression curve to that done under the first compression curve; springiness $(\%)=$ ratio of the distance that sample recovers after the first compression; and chewiness $(\mathrm{N})=$ hardness $\mathrm{x}$ cohesiveness $\mathrm{x}$ springiness (Bourne, 2002). Eight pieces of sausage were measured for each sample.

\section{Scanning electron microscopy}

Microstructure of both cooked and sterilized sausages samples were analyzed by scanning electron microscopy (SEM) according to Horita et al., 2014 with slight modifications. The sample was cut into a piece of approximately $10 \times 5 \mathrm{~mm}$ and fixed in $2.5 \%$ glutaraldehyde in $0.1 \mathrm{M}$ phosphate buffer $(\mathrm{pH} 7.2)$ under refrigeration overnight. The fixed sample was washed twice in $0.1 \mathrm{M}$ phosphate buffer $(\mathrm{pH} \mathrm{7.2)}$ ) for $15 \mathrm{~min}$ followed by washing in distilled water for $15 \mathrm{~min}$. The fixed sample was subsequently dehydrated 3 
times with consecutively increasing concentrations of ethanol (30, 50, 70, 95, and $100 \%$ ) for $10 \mathrm{~min}$ and critically-point dried. The sample was then mounted onto a stainless steel stub, sputter coated with gold, and observed using a scanning electron microscope (JEOL JSM IT 500 HR, JEOL Ltd., Tokyo, Japan) at an accelerating voltage of $10 \mathrm{kV}$. Several micrographs were captured in order to select the most representative one.

\section{Statistical analysis}

Statistical analysis was conducted using SPSS 20.0 (SPSS Inc., Chicago, Illinois, USA). Analysis of variance (one-way ANOVA) and Duncan's multiple range tests were conducted to investigate the statistical significance $(P<0.05)$ of the effect of the sausage formulation with different lipids on the properties of meat emulsions, cooked sausages, and sterilized sausages.

\section{RESULTS}

\section{Emulsion stability}

Stability of pre-emulsified RBOs and meat emulsions expressed as TFR, WR and FR are shown in Tables 2 and 3 respectively. The results show that sample RBO/SPI and RBO/SCM presented fairly low amounts of fluid release with values less than $1 \%$. TFR and WR of sample RBO/SPI were significantly higher than sample RBO/SCM $(P<0.05)$ however there was no significant difference between FR of these 2 samples $(P>0.05)$. While most of the released fluid from $\mathrm{RBO} / \mathrm{SPI}$ was water, water composed only half of the fluid in $\mathrm{RBO} / \mathrm{SCM}$.

Table 2. Emulsion stability of different pre-emulsified rice bran oils.

\begin{tabular}{llll}
\hline Samples & TFR $(\%$ w/w $)$ & WR $(\%$ w/w $)$ & FR $(\%$ w/w $)$ \\
\hline RBO/SPI & $0.37 \pm 0.05^{\mathrm{a}}$ & $0.30 \pm 0.02^{\mathrm{a}}$ & $0.07 \pm 0.04^{\mathrm{a}}$ \\
$\mathrm{RBO} / \mathrm{SCM}$ & $0.12 \pm 0.05^{\mathrm{b}}$ & $0.06 \pm 0.03^{\mathrm{b}}$ & $0.06 \pm 0.03^{\mathrm{a}}$ \\
\hline
\end{tabular}

Notes: Means \pm standard deviation. Different letters in the same column indicate significant difference $(P<$ 0.05). $\mathrm{TFR}=$ total fluid release; $\mathrm{WR}=$ water release; $\mathrm{FR}=$ fluid residue.

Table 3. Emulsion stability of Thai chicken sausages formulated with different types of lipid.

\begin{tabular}{llll}
\hline Samples & TFR $(\% \mathbf{w} / \mathbf{w})$ & WR $(\% \mathbf{w} / \mathbf{w})$ & FR $(\% \mathbf{w} / \mathbf{w})$ \\
\hline Y/CF & $2.01 \pm 0.21^{\mathrm{a}}$ & $1.85 \pm 0.21^{\mathrm{a}}$ & $0.16 \pm 0.01^{\mathrm{a}}$ \\
Y/RBO & $0.91 \pm 0.08^{\mathrm{c}}$ & $0.79 \pm 0.10^{\mathrm{b}}$ & $0.11 \pm 0.04^{\mathrm{a}}$ \\
Y/SPI & $1.67 \pm 0.33^{\mathrm{ab}}$ & $1.54 \pm 0.30^{\mathrm{a}}$ & $0.13 \pm 0.04^{\mathrm{a}}$ \\
Y/SCM & $1.44 \pm 0.40^{\mathrm{bc}}$ & $1.33 \pm 0.38^{\mathrm{ab}}$ & $0.10 \pm 0.02^{\mathrm{a}}$ \\
\hline
\end{tabular}

Notes: Means \pm standard deviation. Different letters in the same column indicate significant difference $(P<0.05) . \mathrm{TFR}=$ total fluid release $; \mathrm{WR}=$ water release $; \mathrm{FR}=$ fluid residue. 
For the meat emulsion samples (Table 3), all 3 emulsion stability parameters showed almost identical behavior in all samples. It can be seen that all samples presented low quantities of fluid release (TFR) in the range of 0.91 to $2.01 \%$. The highest TFR content was found in sample Y/CF (control sample) while the lowest was found in sample Y/RBO. TFRs of sample Y/RBO and Y/SCM were significantly lower than Y/CF $(P<0.05)$, while TFR of sample Y/SPI was not significantly different from Y/CF $(P>0.05)$. Even though both TFR and WR of the pre-emulsified RBO sample RBO/SPI were higher than $\mathrm{RBO} / \mathrm{SCM}$ (Table 2), there were no significant differences between these 2 parameters in the meat emulsion samples, Y/SPI and Y/SCM, which contained each type of pre-emulsified RBO respectively.

Only sample Y/RBO had significantly lower WR than Y/CF, whereas WRs of the rest of the samples were not significantly different. Most of the released fluid was water ranging from 86.8 to $92.4 \%$ of TFR. Sample Y/RBO exhibited the lowest percentage of water in released fluid ( $86.8 \%$ of TFR), while other samples showed very similar content of water in released fluid (around 92\% of TFR). FR of all samples was not significantly different. Although the ratio of fluid residue to total released fluid of sample Y/RBO was highest among the samples.

\section{Texture profile analysis}

Textural properties of cooked Thai chicken sausages is shown in Table 4. The data revealed that all cooked sausage samples containing any type of RBO either frozen (Y/RBO) or pre-emulsified (Y/SPI and Y/SCM) presented significantly higher hardness and chewiness than the control sample which contained chicken fat $(\mathrm{Y} / \mathrm{CF})(P<0.05)$. However hardness and chewiness among these 3 samples, Y/RBO, Y/SPI and Y/SCM, were not significantly different $(P>0.05)$. Although frozen and pre-emulsified RBO had an effect on hardness of cooked sausage samples, there was no significant effect on their cohesiveness and springiness values $(P>0.05)$. Hence, the higher chewiness of sample $\mathrm{Y} / \mathrm{RBO}, \mathrm{Y} / \mathrm{SPI}$ and $\mathrm{Y} / \mathrm{SCM}$ when compared to $\mathrm{Y} / \mathrm{CF}$ originated only from the higher hardness.

Table 4. Texture profile analysis (TPA) of cooked Thai chicken sausages formulated with different types of lipid.

\begin{tabular}{lcccc}
\hline Samples & $\begin{array}{c}\text { Hardness } \\
(\mathbf{N})\end{array}$ & $\begin{array}{c}\text { Cohesiveness } \\
(\boldsymbol{\%})\end{array}$ & $\begin{array}{c}\text { Springiness } \\
(\boldsymbol{\%})\end{array}$ & $\begin{array}{c}\text { Chewiness } \\
(\mathbf{N})\end{array}$ \\
\hline Y/CF & $18.40 \pm 1.99^{\mathrm{a}}$ & $73.83 \pm 0.49^{\mathrm{a}}$ & $88.87 \pm 1.55^{\mathrm{a}}$ & $12.00 \pm 1.45^{\mathrm{a}}$ \\
Y/RBO & $20.79 \pm 1.65^{\mathrm{b}}$ & $73.53 \pm 0.74^{\mathrm{a}}$ & $88.65 \pm 2.55^{\mathrm{a}}$ & $13.57 \pm 1.29^{\mathrm{b}}$ \\
Y/SPI & $21.37 \pm 0.67^{\mathrm{b}}$ & $72.95 \pm 1.01^{\mathrm{a}}$ & $87.37 \pm 1.81^{\mathrm{a}}$ & $13.61 \pm 0.43^{\mathrm{b}}$ \\
Y/SCM & $21.74 \pm 0.42^{\mathrm{b}}$ & $73.07 \pm 0.21^{\mathrm{a}}$ & $88.83 \pm 1.40^{\mathrm{a}}$ & $14.10 \pm 0.52^{\mathrm{b}}$ \\
\hline
\end{tabular}

Notes: Means \pm standard deviation. Different letters in the same column indicate significant difference $(P<0.05)$. 
Sterilized sausages presented almost similar patterns of textural properties to the cooked sausages (Table 5). Sample YS/CF (control sample) still exhibited lower hardness and chewiness than the rest of the samples where chicken fat was replaced by either frozen or pre-emulsified RBO $(P<0.05)$. There were also no significant differences found among the springiness of all sterilized sausage samples $(P>0.05)$. However hardness of sample YS/SCM was significantly higher than sample YS/RBO $(P>0.05)$. This was in contrast to the behavior found in cooked sausage samples in which hardness of sample Y/SCM was similar to Y/RBO and Y/SPI. Even though cohesiveness of all cooked sausage samples was indifferent, the data revealed that cohesiveness of sample YS/SCM was significantly less than sample YS/RBO $(P<0.05)$. Nevertheless, cohesiveness of sample YS/CF remained comparable to YS/SPI and YS/SCM $(P<0.05)$. Thus higher chewiness of sample YS/SCM in comparison to sample $\mathrm{YS} / \mathrm{CF}$ was the consequence of its greater hardness alone whereas for sample YS/RBO this was the combined effect from its hardness and cohesiveness.

Table 5. Texture profile analysis (TPA) of sterilized Thai chicken sausages formulated with different types of lipid.

\begin{tabular}{lcccc}
\hline Samples & $\begin{array}{c}\text { Hardness } \\
(\mathbf{N})\end{array}$ & $\begin{array}{c}\text { Cohesiveness } \\
(\boldsymbol{\%})\end{array}$ & $\begin{array}{c}\text { Springiness } \\
(\boldsymbol{\%})\end{array}$ & $\begin{array}{c}\text { Chewiness } \\
(\mathbf{N})\end{array}$ \\
\hline YS/CF & $16.67 \pm 0.99^{\mathrm{a}}$ & $67.00 \pm 0.61^{\mathrm{ab}}$ & $87.93 \pm 0.81^{\mathrm{a}}$ & $9.69 \pm 0.73^{\mathrm{a}}$ \\
YS/RBO & $19.69 \pm 1.30^{\mathrm{b}}$ & $69.25 \pm 1.48^{\mathrm{c}}$ & $87.68 \pm 1.88^{\mathrm{a}}$ & $11.95 \pm 0.84^{\mathrm{b}}$ \\
YS/SPI & $19.96 \pm 1.63^{\mathrm{bc}}$ & $68.75 \pm 1.37^{\mathrm{bc}}$ & $87.05 \pm 1.38^{\mathrm{a}}$ & $11.92 \pm 1.26^{\mathrm{b}}$ \\
YS/SCM & $21.67 \pm 0.33^{\mathrm{c}}$ & $66.63 \pm 0.45^{\mathrm{a}}$ & $88.13 \pm 2.05^{\mathrm{a}}$ & $12.84 \pm 1.15^{\mathrm{b}}$ \\
\hline
\end{tabular}

Notes: Means \pm standard deviation. Different letters in the same column indicate significant difference $(P<0.05)$.

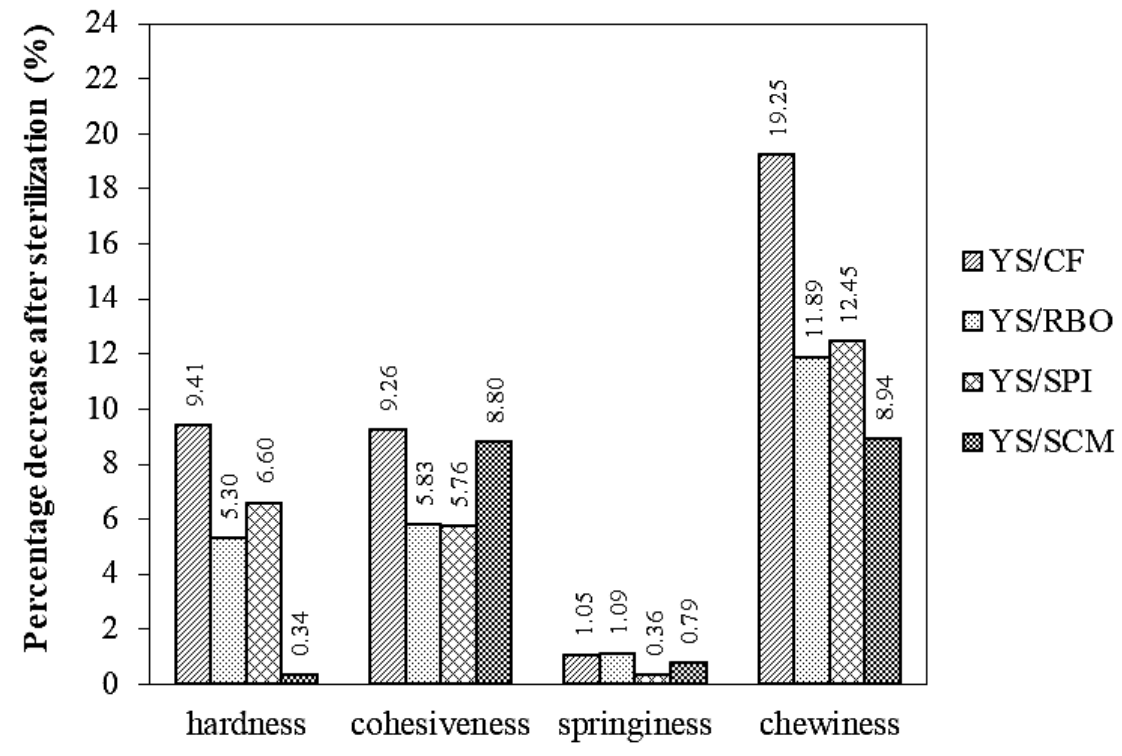

Texture parameters

Figure 1. Reduction in texture parameters of Thai chicken sausages formulated with different types of lipid after sterilization process. 
When cooked sausages were further heated for sterilization, their textural properties apparently changed as shown in Figure 1. All parameters measured by TPA decreased but with different magnitudes. Springiness obviously was the least reduced parameter while chewiness was the greatest. In general, sample YS/CF lost its texture to the highest extent during heat sterilization comparing to the rest of the samples. Slight changes in texture were found in sample YS/SCM expressed by its hardness and chewiness. Although its loss of cohesiveness was larger than samples YS/RBO and YS/SPI yet this loss remained less than sample YS/CF.

\section{Scanning electron microscopy}

SEM images at 1,000x magnification unveiling the morphology of cooked sausages are shown in Figure 2A to 2D. SEM image of sample Y/CF (Figure 2A) showed the typical characteristics of a cooked meat emulsion system, a spongy structure. When compared with other samples, Y/CF contained the smallest number of pores or cavities but with the largest pore size. For sample Y/RBO (Figure 2B), its structure was the most spongy. It had numerous pores consistently distributed all over its structure with the average pore size smaller than Y/CF. The structure of sample Y/SPI was less spongy than $\mathrm{Y} / \mathrm{CF}$ and the pores were smallest (Figure 2C). Sample Y/SCM also contained pre-emulsified RBO but with SC plus SCM, its structure was denser, more compact and had fewer pores than Y/SPI (Figure 2D).

In Figure $2 \mathrm{E}$ to $2 \mathrm{H}$, morphology of sterilized sausages was shown by 1,000x magnification SEM images. Morphological characteristics of sample $\mathrm{YS} / \mathrm{CF}$ was clearly affected by the sterilization process. The pores were enlarged, the structure lost its compactness and marked distortion of the structure occurred (Figure 2E). Sample YS/RBO lost its spongy structure, the pores that were ubiquitous in the cooked sample (Y/RBO) are barely visible and the structure looked denser (Figure 2F). While the structure of samples YS/CF and $\mathrm{YS} / \mathrm{RBO}$ were noticeably changed when compared to their structure prior to sterilization, samples YS/SPI and YS/SCM, which incorporated pre-emulsified oil, showed much less change after sterilization (Figure $2 \mathrm{G}$ and $2 \mathrm{H}$, respectively). In sample YS/SPI, some sponginess was lost and the average pore size was slightly larger than sample Y/SPI. Sample YS/SCM had the slightest change in its morphological characteristics. It was almost identical to sample Y/SCM only with marginal enlarged pores. 

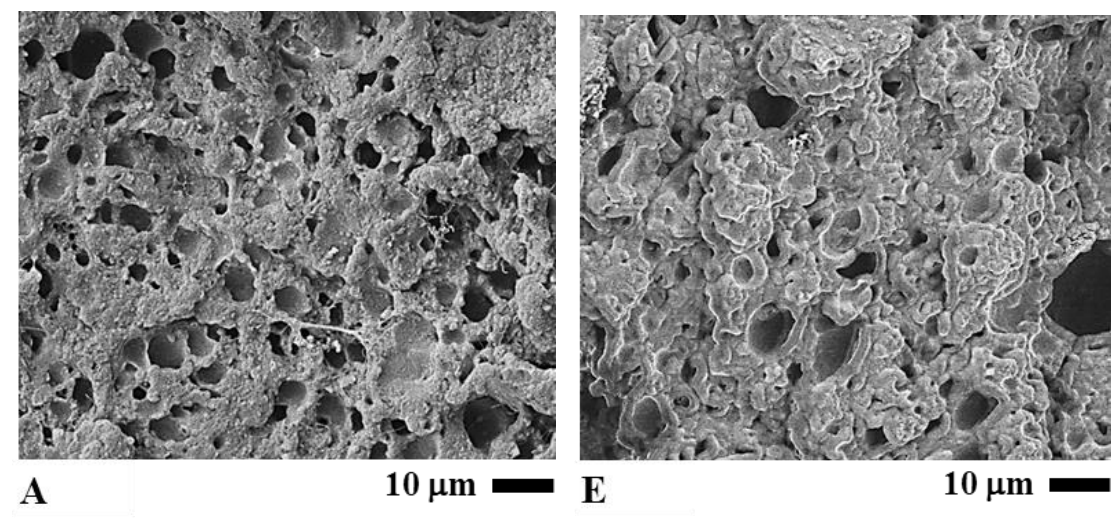

$\mathbf{A}$

$10 \mu \mathrm{m}=\mathrm{E}$
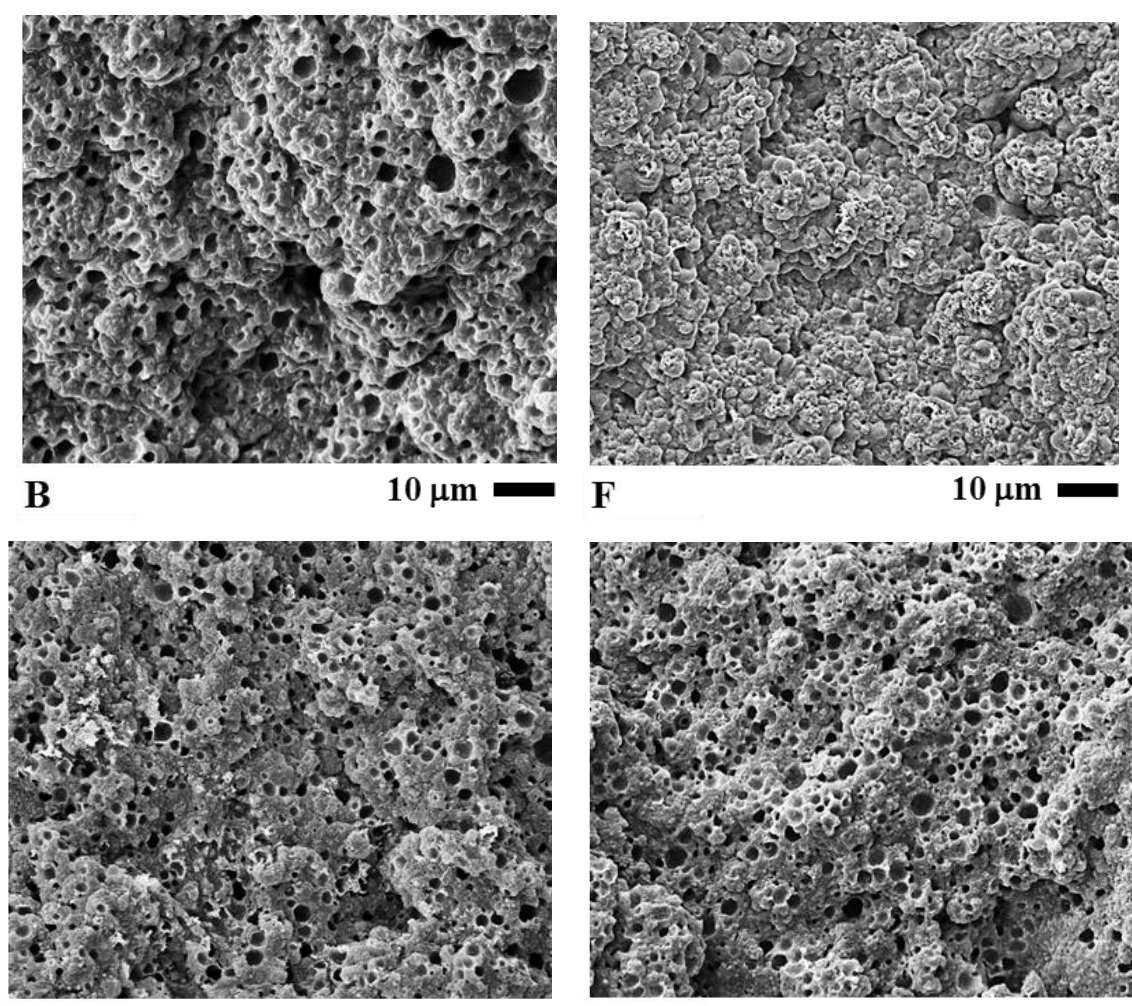

C

$10 \mu \mathrm{m}=\mathrm{G}$

$10 \mu \mathrm{m}=$
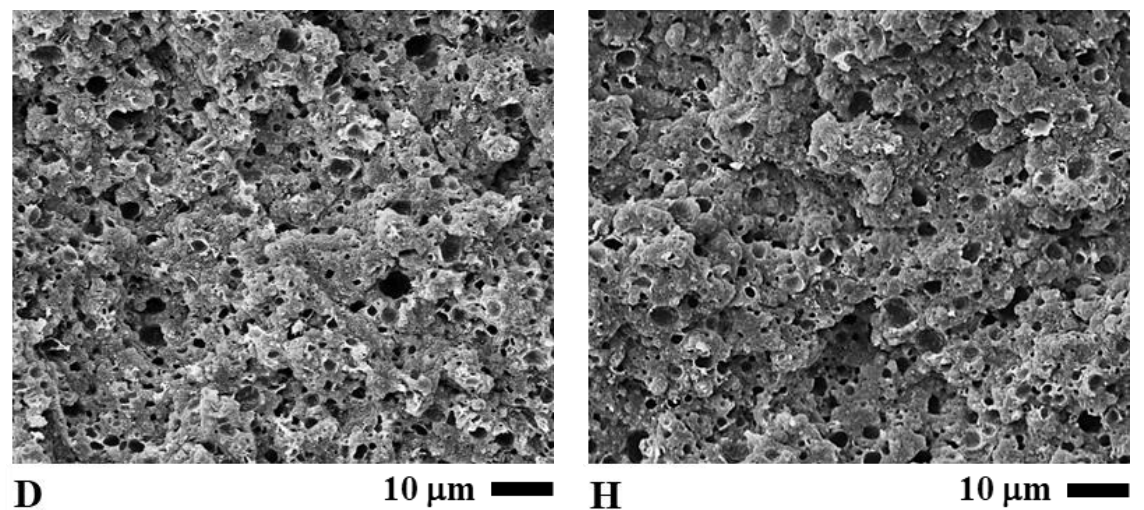

Figure 2. Scanning electron micrographs of Thai chicken sausages formulated with different types of lipid at 1,000x magnification: A) Y/CF, B) Y/RBO, C) Y/SPI, D) Y/SCM, E) YS/CF, F) YS/RBO, G) YS/SPI, and $\mathrm{H}) \mathrm{YS} / \mathrm{SCM}$. Bar represents $10 \mu \mathrm{m}$. 
When SEM images were captured at 5,000x magnification, the network of protein (protein matrix) in meat emulsion structures of the cooked sausage samples could be seen as in Figure 3A to 3D. Sample Y/CF had a fine structure with a fiber-like and sheet-like network combined (Figure 3A). Compare with sample Y/CF, Y/RBO had a coarser structure and contained a mostly thick fiber-like network (Figure 3B). On the contrary, the structure of Y/SPI was mainly comprised of a thick sheet-like network (Figure 3C). Matrix structure of the sample Y/SCM was clearly different from other samples. It had the finest structure and contained only a consistently fine and long fiber-like network (Figure 3D).

At the same 5,000x magnification of the SEM images, protein matrix of the sterilized sausages is shown in Figure $3 \mathrm{E}$ to $3 \mathrm{H}$. It can be seen that the network structure of all samples was somewhat altered by the heat sterilization process; however, the network was not completely eliminated. In sample YS/CF, a sheet-like network disappeared and a fiber-like network was disrupted to quite a high degree (Figure 3E). A sheet-like network in sample YS/RBO was diminished, but the fiber-like network remained (Figure 3F) although this network appeared to be thinner than in sample Y/RBO. Nevertheless a fiber-like network of sample YS/RBO was thicker than that of sample YS/CF. The matrix in sample YS/SPI was apparently damaged, most of a sheet-like network was torn apart into a fiber-like network (Figure 3G) but it still looked denser than sample YS/RBO. In sample YS/SCM, its continuous fiber-like network was altered but retained (Figure $3 \mathrm{H}$ ) despite the fact that this network was thinner than in sample Y/SCM. However the matrix structure of sample YS/SCM was the densest in comparison to the rest of the sterilized sausage.

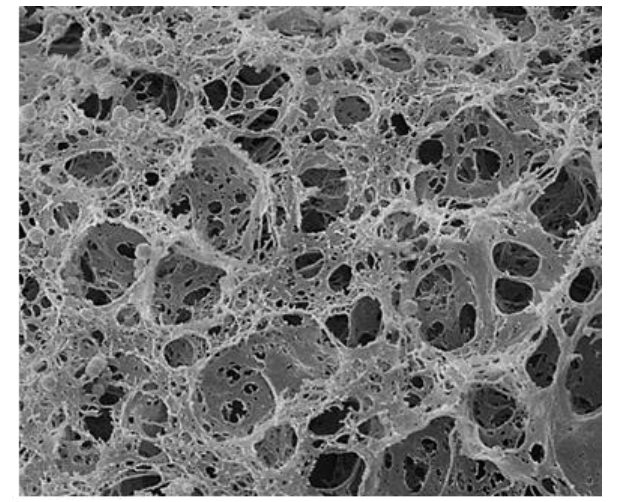

A $5 \mu \mathrm{m}$

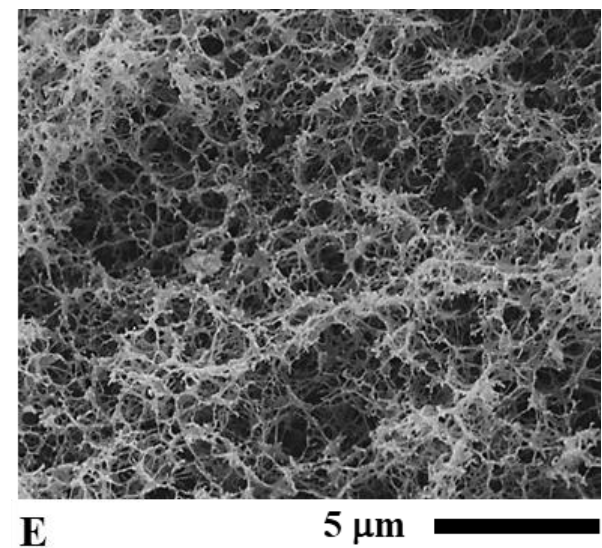

$\mathbf{E}$
$5 \mu \mathrm{m}$

Figure 3. Scanning electron micrographs of Thai chicken sausages formulated with different types of lipid at 5,000x magnification: A) Y/CF, B) Y/RBO, C) Y/SPI, D) Y/SCM, E) YS/CF, F) YS/RBO, G) YS/SPI, and $\mathrm{H}) \mathrm{YS} / \mathrm{SCM}$. Bar represents $5 \mu \mathrm{m}$. 


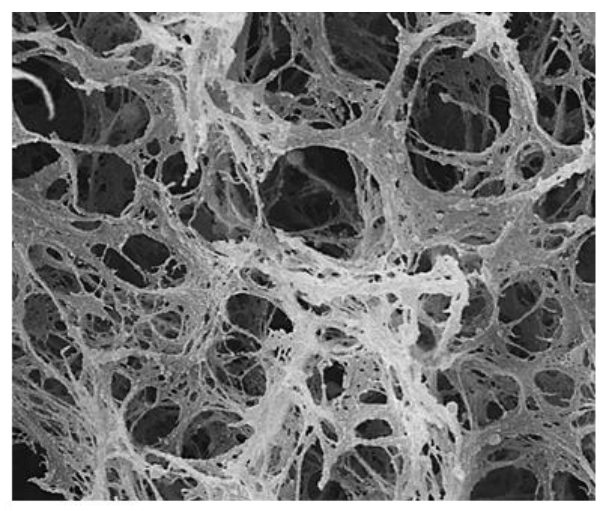

B

$5 \mu \mathrm{m}=\mathrm{F}$

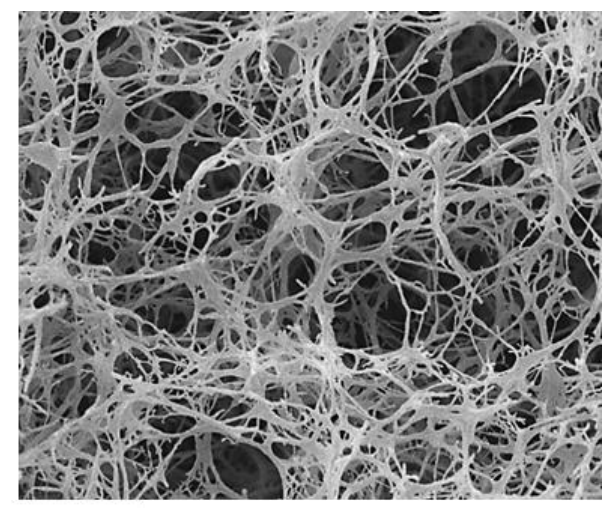

F

$5 \mu \mathrm{m}$

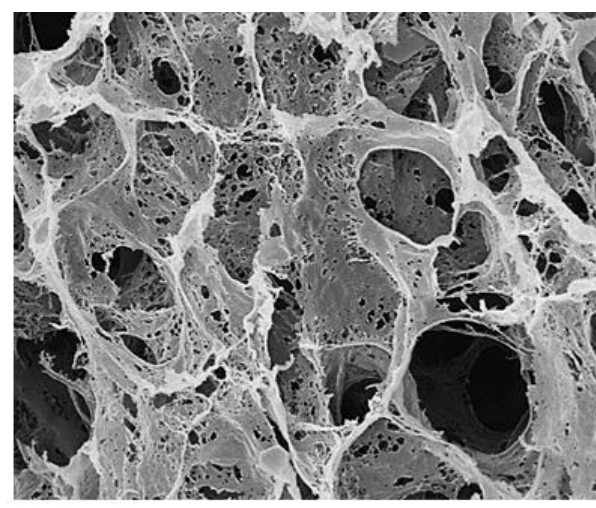

C

$5 \mu \mathrm{m}$

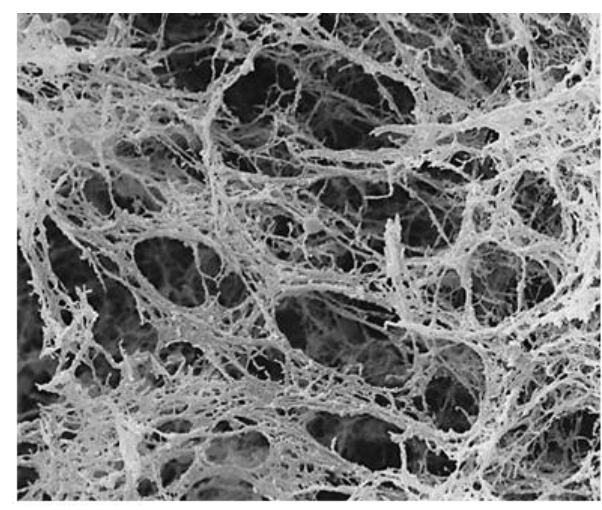

G

$5 \mu \mathrm{m}$

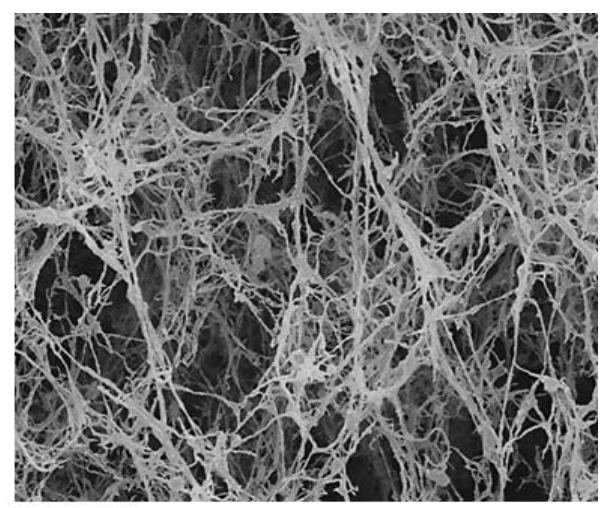

D

$5 \mu \mathrm{m}$

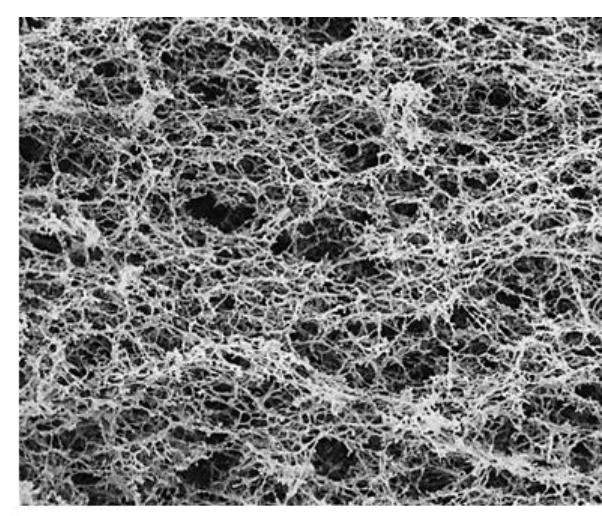

H

$5 \mu \mathrm{m}$

Figure 3. Continued.

\section{DISCUSSION}

Tremendous lipid and water binding characteristics were clearly noticed for both RBO/SPI and RBO/SCM with an almost undistinguishable fluid release after heating. Similar results were reported by Gonzalo-Pando et al., 2010; Jimenez-Colmenero et al., 2010b; Herrero et al., 2011a although with a different type of oil. With their superior properties, Jimenez-Colmenero, 2007 previously reported that pre-emulsified oil stabilized with SPI and/or SC has been widely used in the reformulation of many cooked meat products. Higher emulsion 
stability of RBO/SCM might be due to the interaction of MTG with proteins in the system and this enzyme has been used previously to assist stabilizing an emulsion system made with SC (also with SPI) (Muguruma et al., 2003; Lee et al., 2006) which is a good substrate for MTG (Lee et al., 2006). MTG makes an SC film surrounding RBO droplets in pre-emulsified RBO more rigid by forming lysine-glutamine crosslinking in SC (Delgado-Pando et al., 2010; Gonzalo-Pando et al., 2010; Herrero et al., 2011b). This interaction may have contributed to the fact that pre-emulsified oil prepared with MTG is stiffer and more elastic than the one prepared without MTG (Gonzalo-Pando et al., 2010; Jimenez-Colmenero et al., 2010b).

All meat emulsions had decent stability confirmed by their small amount of fluid release. Typical lipid stabilizing mechanisms in meat emulsion involve the formation of a thin layer of myofibrillar proteins (interfacial protein film or IPF) around lipid globules, and formation of a heat induced protein matrix gel (Gordon and Barbut, 1992). Improvement of stability in sample Y/RBO may originate from smaller and better distributed oil droplets in comparison to the fat globules in sample Y/CF (Youssef and Barbut, 2009; Youssef and Barbut, 2010; Delgado-Pando et al., 2011; Zhuang et al., 2016). Incorporation of preemulsified oil during formulation of meat emulsion, a process known as doubleemulsification, generally enhances the stability of meat emulsion. This may be due to the fact that more myofibrillar protein was available since oil droplets were already stabilized by the non-meat protein added during preparation of pre-emulsified oil, thus less myofibrillar protein was needed for the formation of IPF (Herrero et al., 2012). Carballo et al., 1996 also suggested that changes in the effective concentration of the protein involved in forming the gel/emulsion matrix produced a considerable effect as a result of fat and moisture changes in product formulas. The stability of sample Y/SPI was undoubtedly improved although not sufficient to significantly differentiate from sample Y/CF; this might be explained by large amount of water (42\%) in the RBO/SPI (calculated from the amount of water added in the formulation). On the contrary, stability of sample Y/SCM was improved especially the TFR value, which suggested that MTG could play a major part in stabilizing the system. It has also been shown that MTG develops crosslinking of meat proteins and soluble myofibrillar proteins serving as a good substrate for crosslinking reactions with MTG (Kuraishi et al., 1997). This promotes interactions between meat proteins and casein molecules and fostering formation of a much more stable protein matrix (Kurth and Rogers, 1984).

Textural properties of cooked sausages were influenced by the replacement of chicken fat with either frozen or pre-emulsified RBO, and by the types of stabilizing systems used in the preparation of pre-emulsified RBO. The texture of sample Y/RBO, Y/SPI and Y/SCM were generally improved. It is important to note that since the composition of the sausage mixture (including protein content of the chicken meat) was very similar, the differences in texture 
must be affected mainly by the characteristics of each type of lipid and its role in the protein matrix. This behavior was also proposed by Herrero et al., 2012. Various factors may contribute to the effect of substituting vegetable oils for animal fat on the texture of meat products including the fat source characteristics and their distribution in the protein matrix (Hong et al., 2004; Martin et al., 2008). Previous research also suggested that different lipids and thermal treatments induced different changes in meat product textural properties (Shao et al., 2011). Youssef and Barbut, 2009, 2010 reported that meat products prepared with non-emulsified canola oil presented smaller lipid globules and showed greater hardness than those prepared with beef fat containing larger globules. This was attributed to a larger quantity of small globules present in a given volume and/or a larger surface area covered by proteins, allowing more bonding to the matrix (Youssef and Barbut, 2009). Many researchers have observed heightened firmness in cooked meat products prepared with preemulsified vegetable or fish oil as animal fat replacer (Delgado-Pando et al., 2010; Jimenez-Colmenero et al., 2010b; Carmona et al., 2011; Shao et al., 2011; Youssef and Barbut, 2011). Muguruma et al., 2003 also reported that addition of biopolymers prepared from proteins (soy protein, casein, whey protein isolate) and MTG in a sausage mixture improved sausage texture by increasing its breaking stress. In the same way, the addition of MTG to olive oil-in-water emulsion probably promotes protein-protein interactions in the meat emulsion (Lee et al., 2006; Herrero et al., 2011a, 2011b).

The morphology of sample Y/CF was a distinctive feature of cooked emulsion, referring to a spongy honeycomb-like appearance as described earlier by Carballo et al., 1996. This was the outcome of aggregation of the protein matrix that lost continuity and exhibited an irregularly denser structure (Jimenez-Colmenero et al., 2010b). The pores in the structure might be produced by the expansion of compositions in the meat emulsion including lipids, water or air (Delgado-Pando et al., 2011). The highly spongy structure of Y/RBO might be traced back to a better distribution of a vast amount of small oil droplets in the meat emulsion when compared to lower amounts of large fat globules in Y/CF as discussed earlier. While the more compact and less spongy structure of Y/SPI and Y/SCM might be explained by limited interaction between RBO and protein matrix. This originated during pre-emulsification of oil when non-meat protein molecules (soy protein or casein) diffused to and adsorbed at the oil droplet-water interface, formed a continuous cohesive film, and eventually stabilized the oil (Das and Kinsella, 1990). This process may subsequently restrict the involvement of pre-emulsified oil in the oil-protein interaction which generally developed during meat emulsion formation. Thus, greater dispersion of lipid occurred and brought smaller oil droplets to be embedded into the protein matrix when RBO/SPI and RBO/SCM were incorporated into the meat batter during chopping (Herrero et al., 2012). This illustrated that physical entrapment mechanism as proposed by Barbut (1999) in 
which lipid globules are entrapped directly in a protein matrix gel, plays a greater role in lipid stabilization in sample Y/SPI and Y/SCM. By contrast, $\mathrm{Y} / \mathrm{CF}$ and $\mathrm{Y} / \mathrm{RBO}$ may have more lipid-protein interactions, with the formation of IPF around the lipid globules. The denser appearance of Y/SCM in comparison to Y/SPI might be the collaborative effect of MTG in strengthening emulsion structure through protein crosslinking. Previous studies revealed that morphology of the sausage containing pre-emulsified oil and MTG presented more cavities due to smaller lipid globules. This lead to a larger surface area covered by denser protein matrix structure which also resulted in firmer products (Delgado-Pando et al., 2010; Jimenez-Colmenero et al., 2010b).

Following sterilization, it can be implied that protein matrix was disrupted by heat to different levels fully dependent on the type of lipid trapped in the matrix, lipid stabilizing mechanism, and the robustness of the protein matrix itself. The less disrupted structure of sample YS/SPI and YS/SCM might be related to stronger matrix from double-emulsification process (IPF made of non-meat proteins) and better distributed oil droplets. The specific characteristics in which a large portion of pre-emulsified oil droplets probably embedded in the protein matrix (physical entrapment) might have a significant effect as well. By contrast, sample YS/CF and YS/RBO that suffered a greater degree of damage by heat had a different arrangement of lipid in which fat globules or oil droplets were enclosed by IPF made of myofibrillar proteins in meat. However, oil droplets in YS/RBO were smaller and better distributed, leading to more robust matrix and slightly less damage compared to YS/CF. Moreover, in particular for YS/SCM the activity of MTG when combined with suitable substrate (casein) made a large contribution in strengthening the matrix structure and its thermal stability. Since it has been established that morphological and textural properties of gel/emulsion systems are related (Carballo et al., 1996; Jimenez-Colmenero et al., 2010b), changes in texture (TPA) of sterilized sausage samples reflected the similar trend as changes in their microstructure (SEM).

\section{CONCLUSION}

In summary, frozen $\mathrm{RBO}$ and pre-emulsified RBO with SC+MTG increased the stability of meat emulsion. Hardness and chewiness of cooked meat emulsions formulated with all types of RBO were higher than control. Sterilized meat emulsions prepared with all types of RBO presented higher hardness and chewiness than control. Even though the sterilization process negatively affected texture parameters of all samples, the sterilized meat emulsion formulated with pre-emulsified RBO with SC+MTG had the lowest percentage decrease in hardness and chewiness. Differences in lipid phase affected microstructure of meat emulsions and heat sterilization altered and disrupted the protein matrix in the meat emulsion to different extents depending 
on the type of lipid phase. Replacing chicken fat with pre-emulsified RBO with $\mathrm{SC}+\mathrm{MTG}$ resulted in greater formation of protein matrix which was less severely damaged following sterilization than other types of lipid. It can be concluded that substitution of chicken fat by all types of RBO showed the potential for producing cooked meat emulsion with better quality. In addition, to achieve a satisfactory quality of sterilized meat emulsion, pre-emulsified RBO with SC+MTG offered superior alternative since its microstructure can better withstand the heat treatment during sterilization process.

\section{ACKNOWLEDGEMENTS}

This study was supported by Thammasat University Research Fund, Contract No. TUFT 7/2562, and Thammasat University Center of Excellence in Food Science and Innovation. The authors would like to gratefully thank Ajinomoto Co. Ltd. for providing a microbial transglutaminase enzyme and Vicchi Enterprise Co. Ltd. for providing soy protein isolate and sodium caseinate.

\section{REFERENCES}

Barbut, S. 1999. Advances in determining meat emulsion stability. In: Xiong, Y.L., Ho, C., and Shahidi, F. editors. Quality attributes of muscle foods. New York: Kluwer Academic/ Plenum Publishers. p.353-364.

Bourne, M.C. 2002. Food texture and viscosity: concept and measurement. $2^{\text {nd }}$ edition. New York: Academic Press.

Carballo, J., Fernandez, P., Barreto, G., Solas, M.T., and Jimenez-Colmenero, F. 1996. Morphology and texture of bologna sausage containing different levels of fat, starch and egg white. Journal of Food Science. 61: 652-655. https://doi.org/10.1111/j.1365-2621.1996.tb13179.x

Carmona, P., Ruiz-Capillas, C., Jimenez-Colmenero, F., Pintado, T., and Herrero, A.M. 2011. Infrared study of structural characteristics of frankfurter formulated with olive oil-in-water emulsion stabilized with casein as pork backfat replacer. Journal of Agricultural and Food Chemistry. 59: 12998-13003. https://doi.org/10.1021/jf203941b

Choi, Y.S., Choi, J.H., Han, D.J., Kim, H.Y., Lee, M.A., Kim, H.W., Lee, J.W., Chung, H.J., and Kim, C.J. 2010. Optimization of replacing pork back fat with grape seed oil and rice bran fiber for reduced-fat meat emulsion systems. Meat Science. 84: 212-218. https://doi.org/10.1016/j.meatsci. 2009.08.048 
Das, K.P., and Kinsella, J.E. 1990. Stability of food emulsions: physicochemical role of protein and nonprotein emulsifiers. In J. E. Kinsella editor. Advances in food and nutrition research. London: Academic Press. p. 81201.

Delgado-Pando, G., Cofrades, S., Ruiz-Capillas, C., and Solas, M.T. 2011. Low-fat frankfurters formulated with a healthier lipid combination as functional ingredient: microstructure, lipid oxidation, nitrite content, microbiological changes and biogenic amine formation. Meat Science. 89: 65-71. https://doi.org/10.1016/j.meatsci.2011.03.022

Delgado-Pando, G., Cofrades, S., Ruiz-Capillas, C., Solas, M. T., and JimenezColmenero, F. 2010. Healthier lipid combination oil-in-water emulsions prepared with various protein systems: an approach for development of functional meat products. European Journal Lipid Science Technology. 112(7): 791-801. https://doi.org/10.1002/ejlt.200900234

Genccelep, H., Saricaoglu, F.T., Anil, M., Agar, B., and Turhan, S. 2015. The effect of starch modification and concentration on steady-state and dynamic rheology of meat emulsions. Food Hydrocolloids. 48: 135-148. https://doi.org/10.1016/j.foodhyd.2015.02.002

Gonzalo-Pando, G., Cofrades, S., Ruiz-Capillas, C., Solas, M., and JimenezColmenero, F. 2010. Characteristics of oil (healthier lipid combination)in-water emulsions prepared with various protein systems: an approach for the development of functional meat products. European Journal of Lipid Science and Technology. 112(7): 791-801. https://doi.org/10.1002/ ejlt.200900234

Gordon, A., and Barbut, S. 1992. Mechanisms of meat batter stabilization: a review. Critical Review in Food Science and Nutrition. 32: 299-332. https://doi.org/10.1080/10408399209527602

Herrero, A.M., Carmona, P., Pintado, T., Jimenez-Colmenero, F., and Ruiz-Capillas, C. 2011a. Olive oil-in-water emulsions stabilized with caseinate: elucidation of protein-lipid interactions by infrared spectroscopy. Food Hydrocolloids. 25(1): 12-18. https://doi.org/10.1016/ j.foodhyd.2010.04.014

Herrero, A.M., Carmona, P., Pintado, T., Jimenez-Colmenero, F., and Ruiz-Capillas, C. 2011b. Infrared spectroscopic analysis of structural features and interactions in olive oil-in-water emulsions stabilized with soy protein. Food Research International. 44: 360-366. https://doi.org/10. 1016/j.foodres.2010.10.006

Herrero, A.M., Carmona, P., Pintado, T., Jimenez-Colmenero, F., and Ruiz-Capillas, C. 2012. Lipid and protein structure analysis of frankfurters formulated with olive oil-in-water emulsion as animal fat replacer. Food Chemistry. 135(1): 133-139. https://doi.org/ 10.1016/ j.foodchem.2012.04.114 
Hong, G., Lee, S., and Min, S. 2004. Effects of replacement pork backfat with soybean oil on the quality characteristics of spreadable liver sausage. Food Science and Biotechnology. 13: 51-56.

Horita, C.N., Messias, V.C., Morgano, M.A., Hayakawa, F.M., and Pollonio, M.A.R. 2014. Textural, microstructural and sensory properties of reduced sodium frankfurter sausages containing mechanically deboned poultry meat and blends of chloride salts. Food Research International. 66: 29-35. https://doi.org/10.1016/j.foodres.2014.09.002

Jimenez-Colmenero, F. 2007. Healthier lipid formulation approaches in meatbased functional foods: technological options for replacement of meat fats by non-meat fats. Trends in Food Science and Technology. 18(11): 567578. https://doi.org/10.1016/j.tifs.2007.05.006

Jimenez-Colmenero, F., Carballo, J., and Cofrades, S. 2001. Healthier meat and meat products: their role as functional foods. Meat Science. 59(1): 5-13. https://doi.org/10.1016/s0309-1740(01)00053-5

Jiménez-Colmenero, F., Cofrades, S., Lopez-Lopez, I., Ruiz-Capillas, C., Pintado, T., and Solas, M.T. 2010a. Technological and sensory characteristics of reduced/low-fat, low-salt frankfurters as affected by the addition of konjac and seaweed. Meat Science. 84: 356-363. https://doi. org/10.1016/j.meatsci.2009.09.002

Jimenez-Colmenero, F., Herrero, A., Pintado, T., Solas, M.T., and Ruiz-Capillas, C. 2010b. Influence of emulsified olive oil stabilizing system used for pork backfat replacement in frankfurters. Food Research International. 43: 2068-2076. https://doi.org/10.1016/j.foodres.2010.06. 010

Kuraishi, C., Sakamoto, J., Yamazani, K., Susa, Y., Kuhara, C., and Soeda, T. 1997. Production of restructured meat using microbial transglutaminase without salt or cooking. Journal of Food Science. 62: 488-490,515. https://doi.org/10.1111/j.1365-2621.1997.tb04412.x

Kurth, L., and Rogers, P. J. 1984. Transglutaminase catalyzed cross-linking of myosin to soy protein, casein and gluten. Journal of Food Science. 49: 573-576,589. https://doi.org/10.1111/j.1365-2621.1984.tb12471.x

Lee, H.A., Choi, S.J., and Moon, T.W. 2006. Characteristics of sodium caseinate- and soy protein isolate-stabilized emulsion-gels formed by microbial transglutaminase. Journal of Food Science. 71(6): C352-C357. https://doi.org/10.1111/j.1750-3841.2006.00110.x

Marchetti, L., Andres, S.C., and Califano, A.N. 2013. Textural and thermal properties of low-lipid meat emulsions formulated with fish oil and different binders. LWT Food Science and Technology. 51(2): 514-523. https://doi.org/10.1016/j.lwt.2012.12.006 
Martin, D., Ruiz, J., Kivikari, R., and Puolanne, E. 2008. Partial replacement of pork fat by conjugated linoleic acid and/or olive oil in liver pates: effect on physicochemical characteristics and oxidative stability. Meat Science. 80: 496-504. https://doi.org/10.1016/j.meatsci.2008.01.014

Muguruma, M., Tsuruoka, K., Katayama, K., Erwanto, Y., Kawahara, S., Yamauchi, K., et al. 2003. Soybean and milk proteins modified by transglutaminase improves chicken sausage texture even at reduced levels of phosphate. Meat Science. 63: 191-197. https://doi.org/10.1016/S03091740(02)00070-0

Oezvural, E.B., and Vural, H. 2008. Utilization of interesterified oil blends in the production of frankfurters. Meat Science. 78: 211-216. https://doi. org/10.1016/j.meatsci.2007.06.012

Phisantia, K., and Theprugsa, P. 2018. Use of phosphate replacer in ready-to-eat Kai Yor (Thai chicken sausage) packed in retort pouch. Thammasat Journal of Science and Technology. 26: 121-135. (in Thai)

Saksomboon, K., and Theprugsa, P. 2015. Development of Thai chicken sausage (Kai Yo) by substituting chicken fat with frozen rice bran oil. Thammasat Journal of Science and Technology. 23: 797-804. (in Thai)

Shao, J.H., Zou, Y.F., Xu, X.L., Wu, J.Q., and Zhou, G.H. 2011. Evaluation of structural changes in raw and heated meat batters prepared with different lipids using Raman spectroscopy. Food Research International. 44: 29552961. https://doi.org/10.1016/j.foodres.2011.07.003

Vural, H., and Javidipour, I. 2002. Replacement of beef fat in frankfurters by interesterified palm, cottonseed and olive oils. European Food Research and Technology. 214: 465-468. https://doi.org/10.1007/s00217-002-05025

Youssef, M.K., and Barbut, S. 2009. Effects of protein level and fat/oil type on emulsion stability, texture, microstructure and color of meat batters. Meat Science. 82(2): 228-233. https://doi.org/10.1016/j.meatsci.2009.01.015

Youssef, M.K., and Barbut, S. 2010. Physicochemical effects of the lipid phase and protein level on meat emulsion stability, texture, and microstructure. Journal of Food Science. 75: S108-S114. https://doi.org/10.1111/j.17503841.2009.01475.x.

Youssef, M.K., and Barbut, S. 2011. Fat reduction in comminuted meat products: effects of beef fat, regular and pre-emulsified canola oil. Meat Science. 87(4): 356-360. https://doi.org/10.1016/j.meatsci.2010.11.011

Zhuang, X., Han, M., Kang, Z., Wang, K., Bai, Y., Xu, X., and Zhou, G. 2016. Effects of the sugarcane dietary fiber and pre-emulsified sesame oil on low-fat meat batter physico-chemical property, texture, and microstructure. Meat Science. 113: 107-115. https://doi.org/10.1016/ j.meatsci.2015.11.007 